Vasylenko Olha, Kostyuk Lesya. The Peculiarities of the Formation of Ukrainian-Language Translations of Ernest Hemingway's Works in the $\mathbf{X X}^{\text {th }}$ Century. The article deals with the study of the historical backgrounds for the emergence of Ukrainian-language translations of Ernest Hemingway's works in the twentieth century, and the main factors that determined the Ukrainian-language practice. It is noted that the starting point of this difficult process was the publication in the late 70s - early 80s of the last century of a four-volume edition of Hemingway's works in Ukrainian translation. One of the urgent objects of the translation search is the works of fiction of modern and postmodern directions.

The manner of the writer is characterized as concise, restrained, economical and strict. Considering this fact, the translator must select the language equivalents of the translation carefully, avoiding literalism, and considering the analysed work as a whole system that conveys the storyline. An important step in establishing the practice of translating the works of E. Hemingway was the recession from vocabulary literalism to contextual equivalent to the original.

The article determines the main characteristics of Hemingway's works' Ukrainian modern interpretations, such as the usage of phraseological units while translating direct speech and dialogues, the usage of authentic Ukrainian words considering the character's sex, age and social status. The usage of pragmatic adaptation is also frequent.

The ways of expressing the individual manner of Ernest Hemingway with the methods of fiction of the Ukrainian language are analyzed considering national features. The parallels between the social and cultural life of Ukraine are conducted in the conditions of the twentieth century and the growth of the translating activity on the basis of that of Hemingway's works.

It is indicated that the social-political situation in Ukraine restrained the development of translating practice: antiUkrainian policy blocked the publishing of Ukrainian translations. The negative attitude towards the plots of Hemingway's works was another negative factor.

The main factors which set the vector of translating activity and formed its main tendencies are identified. In the context of social parameters, the ways of their influence and their role in the forming of Ukrainian translating practice are analysed. The main achievements of Ukrainian interpreters in the process of interpretation of Ernest Hemingway's works are singled out.

Key words: individual author's style, translation, translation methods, lexical transformation, contextual equivalent.

DOI: https://doi.org/10.32782/2410-0927-2020-12-6

УДК 371:811.111

Світлана Волох

\title{
ВИКОРИСТАННЯ ІГРОВИХ ТЕХНОЛОГІЙ НА ПРАКТИЧНИХ ЗАНЯТТЯХ 3 АНГЛІЙСЬКОЇ МОВИ В ЗАКЛАДАХ ВИЩОЇ ОСВІТИ
}

У статті висвітлено питання застосування ігрових технологій у навчанні англійської мови в закладах вищої освіти, зіставлено традиційні підходи до навчання та ігрові технології. Досліджено сутність поняття гейміфікації в освітньому процесі, визначено іï переваги та недоліки порівняно з традиційними методами навчання, наведено приклади застосування гейміфікації в освіті. Завданням статті $є$ обгрунтувати сприяння розвитку нових, прогресивних підходів до навчання та розширення використання їх під час практичних занять 3 англійської мови у вищій школі. У дослідженні застосовано описовий і зіставний методи, а також процедуру класифікації для аналізу явища гейміфікації та визначення її основних рис.

На сучасному етапі традиційні форми та методи навчання дійсно стають менш ефективними серед молоді через те, що молоді люди мають низьку мотивацію до навчання та їхнє повсякденне життя перенасичене використанням електронних гаджетів. Тому одним із засобів покращення навчання є використання ігрових технологій, або “гейміфікація”, Digital Game Based Learning (DGBL) - навчання, під час якого використовуються комп’ютерні ігри.

Основними перевагами гейміфікації $\epsilon$ мотивація студентів, залучення їх до активної діяльності, запровадження елементу змагання, заохочення, докладання більших зусиль до навчання та концентрації уваги, поліпшення атмосфери на занятті. Використання гейміфікації можливе без інформаційних технологій, але використання комп’ютерних ігор або онлайн - компонента збагатить навчальні ігри та піде на користь підготовці фахівців. Труднощами запровадження гейміфікації в навчальний процес визначено трудомісткість підготовки навчальних завдань, необхідність використання технічних засобів, можливі складнощі у використанні ТЗН на заняттях і комп'ютерна грамотність викладачів.

В Україні гейміфікація не є поширеною, проте 3 огляду на ряд переваг у порівнянні традиційними підходами може бути поступово впровадженою в освітній процес з метою осучаснення викладання іноземних мов у ЗВО України. Прикладами використання ігрових технологій у навчанні $є$ інтернет-сервіси і освітні платформи. Duolingo - це сервіс для самостійного вивчення іноземної мови, який разом із тим надає послугу щодо його використання в навчальних закладах. Edmodo та Kahoot є навчальними платформами на основі ігор, які можливо використовувати на заняттях іноземної мови.

(C) Волох С., 2020 
Гейміфікація допомагає ефективно навчати, мотивує співпрацю і взаємодію між учасниками, але слід пам'ятати, що використання ігрових технологій у 3ВО - це не розвага і не заміна викладача. Гейміфікація освітнього процесу, на думку автора, у певних випадках є більш ефективною в навчанні сучасних студентів порівняно 3 традиційними методами і вдало доповнює їх. 3 огляду на це важливим є впровадження помірної гейміфікації у навчальний процес в Україні з урахуванням усіх переваг і труднощів реалізації цього явища.

Ключові слова: гейміфікація, ігрові технології, гра, ігрова діяльність, гейміфікація освіти.

Вступ. 3 виникненням перших університетів освіта стала важливою сферою існування людського суспільства. Найголовнішою метою освіти було і залишається забезпечення навчання на високому рівні. У XXI сторіччі відбуваються неймовірні зміни в усіх сферах людського життя, і певним чином це стосується сучасної освіти і технологій навчання. Сучасна молодь народилася в період, у якому панують інтерактивні технології, наприклад, смартфони, комп'ютери та інші сучасні пристрої. На них вони витрачають свій вільний час, перебуваючи в інтерактивно-ігровому середовищі, тому застарілі методи навчання не викликають у них зацікавленості та інтересу до навчального процесу. Отже, впровадження сучасних освітніх технологій у навчання є дуже важливим і актуальним питанням для залучення студентів до активного навчання та підвищення мотивації, якості й майбутнього розвитку системи вищої освіти в Україні.

Проблемі використання інформаційно-комунікаційних технологій в освіті присвячені роботи науковців В. Ю. Бикова, С. А. Ракова, О. В. Співаковського, Р. С. Гуревича та ін. Сучасні освітні підходи досліджували у своїх роботах М. Левін, Н. В. Морзе, А. Б. Качарян та ін. Питання використання комп'ютерних ігор в освітніх цілях досліджено А. М. Бершадським та Е. Е. Янко [9, с. 113-123]. Дослідження науковців вказують на те, що ігри мають позитивний вплив на наше життя, створюють атмосферу оптимізму й допитливості та посилюють соціальні відносини.

Гра є одним із найдавніших методів навчання через те, що людина з раннього дитинства починає досліджувати навколишній світ за допомогою ігор та іграшок. Гра дозволяє людині актуалізувати набуті знання, генерувати нові ідеї, приймати на себе нові ролі без ризику для неї, допомагає підготуватися до реалій професійного життя. Саме тому ігрові методи засвоєння знань $є$ одним із найефективніших способів вивчення та засвоєння нової інформації.

Аналіз останніх досліджень та наукових публікацій 3 питань застосування ігрових технологій в освітньому просторі визначив актуалізацію науковцями нового напряму, що може бути представленим як сучасний спосіб збагачення освітнього процесу. У працях К. Вербах, Д. Хантер, Ю. Чою, Г Зіхерманн, А. Клег цей напрям позначений як гейміфікація [1, с. 129-135].

На думку Гейба Зіхерманна, гейміфікація - це залучення технологій і ігрових «механік» та мотивація людей за допомогою використання внутрішніх стимулів. Він вважає, що будь-яка діяльність має бути винагородженою та в процесі гри учасники мають отримати певний статус [19].

К. Вербах акцентує на мотиваційній функції, яка допомагає активізувати діяльність людини [16]. Дотримуючись цієї думки, Д.Хантер зауважує, що гейміфікація дозволяє використовувати компоненти гри для мотивації людей [16]. Такими компонентами можуть бути подарунки, пробники, бейджики тощо.

У сучасній методиці викладання іноземних мов у вищій школі в Україні термін гейміфікачія майже не згадується і $є$ новим поняттям для викладачів іноземних мов, хоча у викладанні мов у світі навчальні ігри вже використовуються десятиріччями. Можна зробити припущення, що поняття гейміфікації викликає асоціації, пов'язані з комп'ютерними іграми, а викладачі іноземних мов, маючи великий арсенал мовних ігор, особливо не потребували залучення інформаційних технологій у навчальний процес. Проте, по-перше, ми не можемо стверджувати, що гейміфікація неможлива без інформаційних технологій. По-друге, використання комп'ютерних ігор або онлайн-компонента тільки збагатить вищезгадані навчальні ігри та піде на користь підготовці фахівців [17].

На нашу думку, поняття гейміфікації необхідно запровадити в методику викладання іноземних мов у ЗВО для того, щоб іти в ногу з часом та відповідати вимогам сучасної освіти.

Мета статті - розкрити сутність поняття "гейміфікація", з'ясувати іiі переваги та недоліки, порівняти традиційні підходи до навчання та гейміфікацію, розглянути приклади 
використання гейміфікації в навчанні та дослідити стан гейміфікації в Україні. Завданням статті $\epsilon$ сприяння розвитку нових, прогресивних підходів до навчання та розширення використання їх під час практичних занять 3 англійської мови у вищій школі.

Методи та методики дослідження. У дослідженні застосовано описовий і зіставний методи, а також процедуру класифікації для аналізу явища гейміфікації та визначення іiі основних рис.

Результати та дискусії. Явище "гейміфікація" (gamification), тобто використання ігрових практик та механізмів у неігровому контексті для залучення учасників до розв'язання проблем у різних сферах життєдіяльності людини як одне 3 найефективніших для підвищення результативності навчання, не $\epsilon$ новим [13, с. 9-15].

Одна із перших згадок використання елементів гейміфікації датована 1896 роком. Компанія Sperry \& Hutchinson випустила спеціальні марки (S\&H Green Stamp), які видавали покупцям роздрібних магазинів, автозаправок тощо. Зібрані марки вклеювали в спеціальний альбом. У подальшому їх можна було обмінювати на цінні подарунки [5].

Цей метод залучення клієнтів став популярним, і його перейняли інші компанії. Але в XXI сторіччі він набрав нових форм і широкого розповсюдження завдяки британському розробнику відеоігр Ніку Пелінгу (Nick Pelling), який 2002 року застосував цей термін під час розробки користувацького інтерфейсу. Це стало основою створення руху Serious Games Initiative, суть якого полягала в тому, щоб об'єднати підприємства, які широко використовували ігрові методи для навчання своїх співробітників.

2010 року ідея гейміфікації була представлена сучасній спільноті та інтегрована у різноманітні бізнес-структури. У квітні 2011 року був зроблений прогноз, що до 2015 року більше ніж 50 відсотків організацій будуть гейміфікувати інноваційні процеси, ринок гейміфікації сягне \$15 млрд, і вона буде мати місце в усіх сферах людської діяльності, зокрема в освіті [6].

2012 року на освітній платформі Coursera було разпочато навчальний курс Кевіна Вербаха "Gamification". Завдяки його відеолекціям мільйони користувачів долучилися до цього курсу [18].

Як бачимо, застосування ігрових технологій почалося зі сфери бізнесу і пізніше було запозичене вищою школою. Шалену популярність гейміфікація здобула 2010 року завдяки отриманим результатам, які наочно продемонстрували іiі ефективність, і вона була запроваджена та представлена спільноті.

Карл Капп подає найширше визначення гейміфікації. Він вважає, що гейміфікація - це “використання ігрових механік, естетика та ігрове мислення, 3 метою залучати людей, мотивувати дії, сприяти навчанню та вирішувати проблеми” [8, с. 10$\rceil.$

На сучасному етапі традиційні форми та методи навчання дійсно стають менш ефективними серед молоді через те, що молоді люди мають низьку мотивацію до навчання та їхне повсякденне життя перенасичене використанням електронних гаджетів. Тому одним із засобів покращення навчання є використання ігрових технологій, або гейміфікація, Digital Game Based Learning (DGBL) - навчання, під час якого використовуються комп’ютерні ігри.

У науково-довідковій літературі, наприклад, у “Великому тлумачному словнику” під поняттям "гра" розуміють підпорядковане сукупності правил, прийомів або основане на певних умовах заняття [2, с. 257]. У грі беруть участь дві або більше сторін, які ведуть боротьбу за реалізацію своїх інтересів. Кожна зі сторін має свою мету і використовує певну тактику гри, яка веде до перемоги або до програшу залежно від поведінки інших гравців.

Гейміфікація була досліджена в декількох царинах, серед яких взаємодія 3 клієнтами, виконання фізичних вправ, повернення інвестицій, якість даних, пунктуальність та навчання. Більшість досліджень з ігровізації показали позитивні тенденції після гейміфікації [5].

Кевін Вербах, професор Пенсільванського університету, визначив гейміфікацію як “використання елементів гри та ігрових технік у неігровому контексті” [16].

Під гейміфікацією в освіті вважаємо застосування ігрових технік, практик та ігор 3 освітньою метою.

Науковець К. Вербах зображує структуру гейміфікації у вигляді піраміди (рис. 1). 


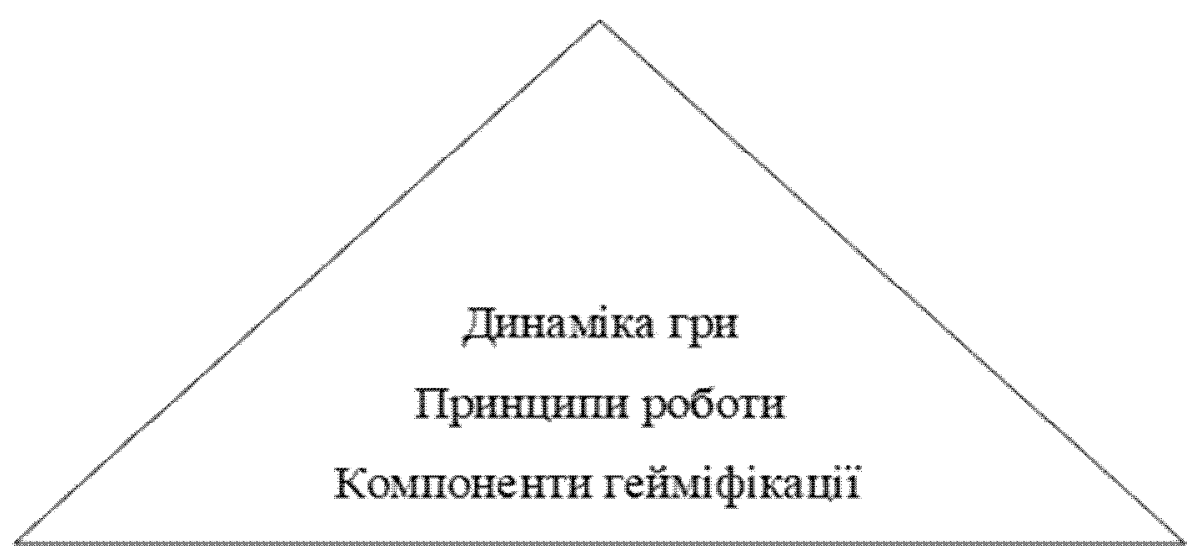

Рис. 1. Структура гейміфікаиії за професором К. Вербахом

Розглянемо структуру детальніше. Під компонентами гейміфрікації розуміють зовнішні атрибути, такі як аватар, бали, рівні, віртуальні предмети, таблиці результатів, досягнення чи винагороди. До принципів роботи належать чинники, що мотивують гравця продовжувати гру, просуватися вперед. Іншими словами, це правила, змагання, стосунки 3 партнером по грі та зворотний зв'язок. Динаміка гри (з грец. -dynamixos - той, що має силу, от dunamis - сила) - це одна 3 характеристик ігрового процесу. Описати ії можливо як кількість цікавих подій за одиницю часу або сюжетний відрізок.

Основними аспектами гейміфікації є:

- динаміка - використання сюжетів та сценаріїв гри;

- механіка - набір базових дій, таких як кидки кубиків, рух фішок, витягування карт; нові ігрові механіки з'являються вкрай рідко;

- естетика - краса, художність, загальне враження, що справляє гра;

- соиіальна взаємодія - взаємодія між партнерами гри;

Основні терміни, які використовують у гейміфікованому середовищі:

- гравиі - учасники гри;

- діï - сукупність вчинків гравців для досягнення цілі;

- рівні майстерності - ступінь якості, величина та ін., досягнуті у процесі ігрової діяльності;

- мотивація - сукупність мотивів, доказів для обгрунтування чогось.

Характерними ознаками гри є:

- правила, які відомі всім учасникам;

- у грі беруть участь декілька гравців;

- поведінка кожного з учасників невідома, оскільки кожен з них має

- декілька варіантів дій;

- інтереси гравців можуть збігатися або різнитися;

- результат гри залежить від спільних зусиль усіх учасників.

Звісно, що кожний із підходів (гейміфікація 3 одного боку, традиційне навчання - 3 іншого) має свої переваги та недоліки. Розглянемо та порівняємо їх.

Переваги традиційного підходу до навчання:

1) особисте спілкування між викладачем та студентом;

2) передача та засвоєння великого обсягу інформації в стислому вигляді;

3) міжособистісна взаємодія з іншими студентами в групі та контроль з боку викладача;

4) обговорення з викладачем незрозумілого матеріалу.

Переваги гейміфікащиї:

1) використання дистанційної форми навчання;

2) можливість використання різних мультимедійних засобів та сучасних технологій; самоконтролю;

3) розкриття творчих здібностей людини, посилення креативного мислення та

4) збільшення інтересу до навчання через цікаве викладання матеріалу, що допомагає підвищити ступінь засвоєння матеріалу. 
Недоліки традищійного підходу до навчання:

1) навчальні матеріали стандартизовані, а це не дає можливості розвиватися здібностям студентів;

2) головна увага спрямована на запам'ятовування інформації, а не мислення та логічне обмірковування; на практиці.

3) значна кількість часу приділяється отриманню нової інформації, а не закріпленню іiі

Недоліки гейміфікаиіï:

1) дефіцит спілкування під час навчання;

2) ймовірність неправильного розуміння теми;

3) шкода для здоров'я в результаті збільшення проведеного часу за комп'ютером;

4) можливі збої під час роботи з електронними пристроями;

5) викладачі потребують спеціальної підготовки для опанування електронними ігровими технологіями.

Отже, гейміфікація, як будь-який інший метод, має свої переваги та недоліки.

Головна перевага гейміфікації в тому, що нова інформація надається поступово, знання закріплюються в ігровій формі, після того, як знання закріплені та вивчений матеріал відпрацьований відбувається перехід до нової теми. Це значно підвищує якість знань та результативність навчального процесу.

Однією з позитивних сторін гейміфікації $є$ те, що активізуються комунікативні якості та навички студентів до командної роботи, самодисципліни й самоорганізації. У процесі виконання завдань зростає зацікавленість та азарт, це підвищує мотивацію студента до вивчення дисципліни.

Під час ігрової діяльності студенти не відчувають великої відповідальності або психологічного тиску, знання засвоюються у ненав'язливій формі.

Отже, застосування гейміфікації в освітньому процесі 3ВО не викликає сумнівів і має цілий ряд переваг, що: 1) мотивують студентів; 2) залучають їх до активної діяльності; 3) змушують більше концентруватися; 4) запроваджують елемент змагання; 5) заохочують докладати більше зусиль до навчання; 6) допомагають сконцентруватися певний час на цьому виді діяльності; 7) поліпшують атмосферу на занятті. Як бачимо, гейміфікація відіграє важливу роль і покращує результати навчальної діяльності студентів.

Запровадження гейміфікації має багато позитивних сторін, але існують і труднощі використання цього методу у навчальному процесі.

Оскільки час, проведений за комп'ютером, збільшується, посилюється негативний вплив на організм молодої людини, зокрема на зір та поставу. Підготовка завдань стає трудомістким процесом і потребує використання специфічних технічних засобів та комп'ютерної грамотності викладачів. Найменші збої з технічного боку (відсутність електропостачання чи Інтернету) унеможливлюють проведення заняття.

3 огляду на широку практику застосування гейміфікації у світі важливим $є$ розгляд стану гейміфікації в Україні для активного впровадження цього сучасного методу у навчання іноземних мов українських учнів, студентів та дорослих.

Закон України "Про вищу освіту” у статті 3 зазначає, що державна політика у сфері вищої освіти реалізується завдяки “розширенню можливостей для здобуття вищої освіти” [7] , але введення ігрових технологій у навчальний процес не набуло значного поширення та офіційного запровадження. Система вищої освіти в Україні є досить консервативною і зміни потребують кропіткої роботи та тривалого періоду часу на впровадження.

Прикладом успішного застосування гейміфікації в навчальному процесі в Україні $\epsilon$ перемога вчительки англійської мови 3 Кіровограда Маргарити Калюжної в номінації "Гейміфікація" на Міжнародному конкурсі "Microsoft E2 - Educator Exchange" у Будапешті 2016 року. Команда Маргарити Калюжної складалася 3 чотирьох вчителів 3 Малайзії, Туреччини, Швейцарії та України. Перед ними було поставлено завдання розв'язати одну 3 актуальних проблем, з якою щодня стикаються вчителі. Команда Маргарити мала знайти рішення, що дозволило б з перших хвилин уроку оволодіти увагою учнів та залучити їх до 
роботи. Для виконання завдання була розроблена ігрова концепція First Five Minutes (Перші п’ять хвилин), яка створює атмосферу змагання та спонукає учнів до навчання [10]. Цей приклад уможливлює подальшу практичну роботу з розроблення ігрових завдань, запевняє у можливості запровадження технології гейміфікації в освітню і навчальну діяльність у ЗВО України.

Зважаючи на певні переваги ігрових методів над традиційними, гейміфікація в освітньому середовищі урізноманітнює процес опанування знань та робить навчання ефективнішим. Прикладами впровадження гейміфікації в навчання $\epsilon$ сервіси i освітні платформи, розроблені як інтернет-інструменти для вивчення іноземної мови.

Duolingo - це сервіс для самостійного вивчення іноземної мови. Уроки побудовані на використанні карток, тестах та аудіюванні. Користувачі можуть коментувати матеріали, а також об'єднуватися для спільного вивчення мови. Ефективність підходу Дуолінго, заснованого на аналізі статистики, була перевірена стороннім дослідженням на замовлення компанії Duolingo 2012 року [12]. Дослідження, проведене професорами Міського університету Нью-Йорка і Університету Південної Кароліни, показало, що 34 години тренування на Дуолінго дають стільки ж навичок читання і письма, скільки дає початковий семестровий курс в американському вищому навчальному закладі об'ємом близько 130 годин. Проте цей аналіз не оцінював розмовні навички.

У Дуолінго користувачі можуть практикувати вивчені слова та отримувати нагороди за вивчений матеріал після кожного уроку. Протягом одного курсу користувач може вивчити до 2000 слів. Після оволодіння належними навичками на уроках видається внутрішня ігрова валюта. ÏÏ можна витрачати в ігровому магазині або дарувати користувачам, які залишили корисний коментар на форумі. На будь-якому рівні вивчення мови можна пройти тест на знання мови, після проходження тесту буде виданий електронний сертифікат. Тест можна проходити неодноразово.

Отже, на думку Сетлез Бурр (Settles Burr), Дуолінго використовує для навчання підхід, що заснований на аналізі великої кількості статистичних даних [14]. На кожному етапі система запам'ятовує, які питання викликали в користувачів труднощі і які помилки були здійснені. Потім вона обробляє ці дані i використовує їх для машинного навчання. Таким чином, формуються індивідуальні уроки.

Дуолінго надає послугу “Дуолінго для шкіл”, яка дозволяє педагогам відстежувати прогрес своїх учнів.

Дуолінго став переможцем у номінації “Кращий освітній стартап” на Crunchies 2014 року і став найбільш завантажуваним додатком у категорії “Освіта” в Google Play у 2013 i 2014 роках. 2015 року ця освітня платформа була оголошена переможцем у категорії "Гра і навчання" в номінації “Дизайн для поліпшення життя” [3].

Інші приклади використання гейміфікації у навчанні - це сервіси Edmodo i Kahoot.

Edmodo - освітня технологічна платформа, що пропонує комунікацію, співпрацю та можливість тренерської роботи для загальноосвітніх шкіл, коледжів та 3ВО. Мережа Edmodo дає викладачам змогу ділитися вмістом, створювати тести, вікторини та опитування, керувати спілкуванням з учнями, студентами, колегами та батьками. Система орієнтована на педагога, студенти можуть приєднатися до Edmodo тільки після запрошення викладачем [4].

Kahoot - це навчальна платформа на основі ігор, яку використовують як навчальну технологію в навчальних закладах різного типу, вона підходить для будь-якого віку. Навчальні ігри "Kahoots" - це вид ігор-вікторин з множинним вибором, що допомагають закріплювати вивчений матеріал. Загалом, таке навчання розроблене для врівноваження теоретичного осмислення предмета 3 процесом гри та для розвитку здатності гравця застосовувати даний предмет у реальному світі [15].

Для того, щоб застосувати процес гейміфікації у викладанні та навчанні за моделлю Хуанг та Соман [11], необхідно виконувати п'ять кроків:

1) визначити цільову аудиторію та форму проведення;

2) окреслити мету навчання;

3) створити чітку структуру;

4) обрати ресурси; 
5) використати елементи гейміфікації.

Насамперед, щоб визначити цільову аудиторію, необхідно знати вік ії представників та навички, якими учасники вже володіють на момент навчання. За специфікою проведення навчальне заняття може бути у формі лекції, практичного чи групового заняття.

Мета заняття передбачає реалізацію трьох функцій: освітньої, розвиваючої та виховної.

Освітня функція забезпечує засвоєння студентами наукових знань, формує вміння i навички. Використання ігрових технологій чудово розв'язує ці завдання, оскільки через ігри можна невимушено сформувати навички і довести їх до автоматизму, вивчити новий матеріал, засвоїти навички та відпрацювати їх, оволодіти умінням самостійно застосовувати знання та застосовувати їх на практиці.

Розвиваюча функція передбачає розвиток у студентів мислення, формування волі, емоційно-почуттєвої сфери, мотивації та творчих здібностей. Виховна функція полягає у формуванні таких моральних якостей: почуття обов'язку, гуманізму, відповідальності, позитивного ставлення до праці, навчання і життя взагалі.

Висновки. Використання ігрових технологій стало популярним у багатьох країнах світу. Гейміфікація допомагає ефективно навчати письма, читання, мовлення та мотивує співпрацю і взаємодію між учасниками, але слід пам'ятати, що використання ігрових технологій у ЗВО - це не розвага і не заміна викладача. Ігрова діяльність - це один із методів навчання, що допомагає активізувати пізнавальну діяльність студентів, підвищує мотивацію до навчання, якість та ефективність навчального процесу. Гейміфікація освітнього процесу, на нашу думку, у певних випадках $є$ більш ефективною в навчанні сучасних студентів порівняно 3 традиційними методами і вдало доповнює їх. 3 огляду на це важливим $\epsilon$ впровадження помірної гейміфікації в навчальний процес в Україні з урахуванням усіх переваг і труднощів реалізації цього явища. Перспективами дослідження $є$ розроблення низки ігрових завдань для розвитку і популяризації напряму гейміфікації в українських $3 \mathrm{BO}$.

\section{References}

1. Buhayeva, Viktoria. 2017. "Heimifikatsiya yak sposib formuvannya aktyvnoyi profesiynoyi povedinky maybutnikh fakhivtsiv IT haluzi”. Pedahohika ta psykholohiya 56:129-135. doi.org/10.5281/zenodo.577567. Accessed February 10, 2020. http://nbuv.gov.ua/UJRN/znpkhnpu ped 20175616

2. Busel, Viacheslav. 2005. Velykyi tlumachnyi slovnyk suchasnoi ukrayinskoi movy. Irpin: Perun.

3. "Duolingo". 2020. Wikipedia, free encyclopedia. Accessed February 19, 2020. https://ru.wikipedia.org/wiki/ Duolingo\#cite note-8

4. "Edmodo". 2020. Wikipedia, free encyclopedia. Accessed February 25, 2020. https://uk.wikipedia.org/ wiki/Edmodo

5. "Gamification". 2020. Wikipedia, free encyclopedia. Accessed February 17, 2020. https://uk. wikipedia.org/wiki/ Heymifikatsiya

6. Gary, Kim. 2011. "Innovation Will Become a Game, Gartner Says". Techzone360, April 15. Accessed February 23. https://www.techzone360. com/topics/techzone/articles/164666-innovation-will-become-game-gartnersays.htm

7. Hsin-Yuan, Wendy, Huang and Dilip Soman. 2013. A Practitioner's Guide to Gamification of Education. Research Report Series: Behavioral Economics in Action. Toronto: Rotman School of Management, University of Toronto.

8. Kapp, Karl 2012. The Gamification of Learning and Instruction: Game-Based Methods and Strategies for Training and Education. San Francisco: Pfeiffer.

9. Lyashchenko, Tamara, Hryshunina, Maryna \& Pichkur, Vladyslav. 2018. "Gamifification as one of the innovative forms of the training process". Management of development of complex systems 35:113-123.

10. Lystiuk, Svitlana. 2016. "Microsoft vyznav kirovohradku odniyeyu z naikrashchykh na Mizhnarodnomu konkursi vchyteliv". Persha elektronna hazeta, March 19. Accessed March 03, 2020. https://persha.kr.ua/ news/life/69929-microsoft-viznav-kirovogradku-odniyeyu-z-najkrashhih-na-mizhnarodnomu-konkursi-vchiteliv

11. Pro vyshchu osvitu: Zakon Ukrainy vid 05.09.2017 № 2145-VIII, rozd. I, p. 3. 2017. Accessed February 10, 2020. https://zakon.help/law/1556-VII/edition01.01.2019

12. Roumen Vesselinov, John Grego. 2012. Duolingo Effectiveness Study. New York: Columbia.

13. Sebastian Deterding, Dan Dixon, Rilla Khaled, and Lennart Nacke. From game design elements to gamefulness: Defining "gamification" Proceedings of the 15th International Academic MindTrek Conference (Association for Computing Machinery, 2011), 9-15.

14. Settles, Burr. 2013. Duolingo's Data-Driven Approach to Education. Official Duolingo Blog. January, 31, 2020. Accessed February 23, 2020. https://duolingo.tumblr.com/post/41960192602 
15. Team Editorial. 2013. "What is GBL (Game-Based Learning)". EdTechReview, April 23. Accessed February 23, 2020. https://edtechreview.in/dictionary/298-what-is-game-based-learning

16. Verbakh Kevin, Khanter Dan. Vovlekay i vlastvuy. Igrovoye myshleniya na sluzhbe biznesa (Moskva: Mann, Ivanov i Ferber, 2015).

17. Warschauer, Mark and Shetzer, Heidi, Meloni, Christine F. 2000. Internet for English Teaching. Alexandria, VA: TESOL.

18. Werbach, Kevin. "Gamification”. Coursera.org. Accessed February 23, 2020. https://www.coursera.org/ learn/gamification

19. Zichermann G. 2011. "The purpose of gamification. A look at gamification's applications and limitations". Radar. O'reilly, April 26. Accessed February 29, 2020. http://radar.oreilly.com/2011/04/ gamification-purposemarketing.html

Волох Светлана. Использование игровых технологий на практических занятиях по английскому языку в учреждениях высшего образования. В статье освещены вопросы применения игровых технологий в обучении английскому языку в учреждениях высшего образования, сопоставлены традиционные подходы к обучению и игровые технологии. Исследована сущность понятия геймификации в образовательном процессе, определены ее преимущества и недостатки по сравнению с традиционными методами обучения, приведены примеры применения геймификации в образовании. Задачей статьи является содействие развитию новых, прогрессивных подходов к обучению и расширение использования их во время практических занятий по английскому языку в высшей школе. В исследовании применен описательный и сопоставительный методы, а также процедура классификации для анализа явления геймификации и определение ее основных черт.

На современном этапе традиционные формы и методы обучения действительно становятся менее эффективными среди молодежи из-за того, что они имеют низкую мотивацию к обучению и повседневная жизнь перенасыщена использованием электронных гаджетов. Поэтому одним из средств улучшения обучения является использование игровых технологий, или геймификация, Digital Game Based Learning (DGBL) - обучение во время которого используются компьютерные игры.

Основными преимуществами геймификации являются: мотивация студентов, привлечение их к активной деятельности, введение элемента соревнования, поощрения, приложения больших усилий к обучению и концентрации внимания, улучшение атмосферы на занятии. Использование геймификации возможно без информационных технологий, но использование компьютерных игр или онлайн-компонента обогатит обучающие игры и пойдет на пользу подготовке специалистов. К трудностям внедрения геймификации в учебный процесс относятся: трудоёмкость подготовки учебных задач, необходимость использования технических средств, возможны затруднения в использовании ТСО на занятиях и компьютерная грамотность преподавателей.

В Украине геймификация не является распространенной, однако, учитывая ряд преимуществ по сравнению с традиционными подходами, может быть постепенно внедрена в образовательный процесс с целью осовременивания преподавания иностранных языков в учреждениях высшего образования Украины. Примерами использования игровых технологий в обучении являются интернет-сервисы и образовательные платформы. Duolingo - это сервис для самостоятельного изучения иностранного языка, который вместе с тем предоставляет услугу его внедрения в учебных заведениях. Edmodo и Kahoot являются учебными платформами на основе игр, которые можно использовать на занятиях иностранного языка.

Геймификация помогает эффективно обучать, мотивирует сотрудничество и взаимодействие между участниками, но следует помнить, что использование игровых технологий в УВО - это не развлечение и не замена преподавателя. Геймификация образовательного процесса, по мнению автора, в определенных случаях является более эффективной в обучении современных студентов по сравнению с традиционными методами и удачно дополняет их. Учитывая это, важно внедрение умеренной геймификации в учебный процесс в Украине с учетом всех преимуществ и трудностей реализации этого явления.

Ключевые слова: геймификация, игровые технологии, игра, игровая деятельность, геймификация в образовании.

Volokh Svitlana. The Usage of Gaming Technologies in Practical English Classes in Higher Educational Institutions. The article highlights the application of game technologies in English language teaching in higher education institutions, compares traditional teaching approaches and game technologies. The essence of the concept of gamification in the educational process is investigated, its advantages and disadvantages in comparison with traditional teaching methods are determined, examples of application of gamification in education are given. The aim of the article is to promote the development of new, progressive approaches to learning and expand their use in practical English classes in high school. The study used descriptive and comparative methods, as well as the classification procedure to analyze the phenomenon of gamification and determine its main features.

At the present stage, traditional forms and methods of teaching are really becoming less effective among young people due to the fact that they have low motivation to learn and everyday life is oversaturated with the use of electronic gadgets. Therefore, one of the means to improve learning is the use of game technology or "gamification", Digital Game Based Learning (DGBL) - learning in which computer games are used.

The main advantages of gamification are motivating students, involving them in active activities, introducing an element of competition, encouragement, making greater efforts to learn and concentrate, improving the atmosphere in the 
classroom. The use of gamification is possible without information technologies, but the use of computer games or online components will enrich educational games and benefit the training of specialists. The difficulties of introducing gamification into the educational process are determined by the complexity of preparation of educational tasks, the necessity of using the technical means, possible difficulties in the use of them in the classroom and computer literacy of teachers.

In Ukraine, gamification is not widespread, however, taking into consideration a number of advantages over traditional approaches, it can be gradually introduced into the educational process in order to modernize the teaching of foreign languages in the higher educational institutions of Ukraine. Examples of the usage of gaming technology in education are online services and educational platforms. Duolingo is a service for self-study of a foreign language, which at the same time provides a service for its use in educational institutions. Edmodo and Kahoot are game-based learning platforms that can be used in foreign language classes.

Gamification helps to teach effectively, motivates cooperation and interaction between participants, but it should be remembered that the use of game technology in institutions is not entertainment or a substitute for the teacher. Gamification of the educational process, according to the author, in some cases is more effective in teaching modern students comparing to traditional methods and successfully complements them. Taking into account the above, it is important to introduce moderate gamification in the educational process in Ukraine, considering all the advantages and difficulties of this phenomenon.

Key words: gamification, gaming technologies, game, game activity, gamification of education.

DOI: https://doi.org/10.32782/2410-0927-2020-12-7

УДК 821.112.2:339.5

Olena Halytska

\section{VON GASTARBEITERLITERATUR ZUR TRANSNATIONALEN LITERATUR? PROBLEMATISIERUNGEN UND FORSCHUNGSFRAGEN}

Innerhalb der Literaturwissenschaft herrscht eine gewisse Begriffsunsicherheit: Es gibt viele verschiedene Begriffe, welche zum Teil bedeutungsgleich verwendet werden, zum Teil allerdings auch mehr oder weniger strikt voneinander unterschieden werden (transnationale Literatur, Chamisso-Literatur, interkulturelle Literatur, diasporische Literatur, Literatur der Betroffenheit, Minderheitsliteratur, Literatur mit dem Motiv der Migration, Literatur der Migration, Fremdliteratur, Literatur der Fremde, Literatur in der Fremde, Ausländerliteratur, Literatur ohne festen Wohnsitz, Gast-, Immigranten-, Emigrations-, Migranten-, Migrationsliteratur, deutsche Gastliteratur, deutsche Literatur von außen, Exilliteratur, die Literatur der (Arbeits-)Migranten. In der Gegenwart wird viel über die Neudefinierungen von Migrantenliteratur "interkulturelle Literatur" und "transnationale Literatur" debattiert und gestritten. Neuere Befunde der Migrationsforschung lassen erkennen, dass soziale und kulturelle Motive vor geographischen und ökonomischen Wanderungsmotiven gegenwärtig dominieren. Zwischen Transmigration und transnationaler Literatur, die in das 21. Jahrhundert hinüberleitet, besteht ein zwingender Zusammenhang. Wichtige Kriterien der transnationalen Literatur sind: die mehrsprachige Erfahrung; die mehrkulturelle Erfahrung in der Minderheitensituation; neue transnationale Erinnerungskulturen, in denen divergente Bedeutungen aufeinandertreffen, zentrale Ereignisse der Geschichte und Persönlichkeiten und Prozesse neu bewertet und tradierte Narrative befragt und transformiert werden. Diese Literatur zeichnet sich durch einen transnationalen respektive transkulturellen Charakter aus. Phänomene der Transnationalität gibt es in der Literatur auf drei Ebenen: Produktion, Thematik und Darstellung, Rezeptio. Dabei ist zu unterscheiden: nach Autoren, die bereits in ihrer Heimat und in ihrer Muttersprache als Autoren waren (Herta Müller (Rumunien), Maynat Kurbatowa (Tschetschenien), Marjana Gaponenko (Ukraine)); nach Autoren, die erst durch die Erfahrung der Migration zum Schreiben kommen (Abbas Khider (Irak), Katja Petrowskaja (Ukraine), Liu Dejun (China)); nach Autoren, die noch in jungem Alter ihre Heimat verlassen mussten und im deutschsprachigen Raum aufgewachsen sind (Z Şenocak, J F A Oliver, Z Çirak, S Özdogan, Feridun Zaimoglu, Saša Stanišić); nach Autoren mit Migrationshintergrund, deren Elternteile beide (oder ein Elternteil) im Ausland geboren wurden, sie sind von Kind an bi- oder trilingual (Shida Bazyar, Sherko Fatah).

Schlüsselwörter: transnationale Literatur, transnationale Erinnerungskulturen, Transmigrant.

Einleitung und Fragestellung. Der Begriff der transnationalen Literatur ist sehr facettenreich und wird stark diskutiert. Innerhalb der Literaturwissenschaft herrscht eine gewisse Begriffsunsicherheit und es deshalb wichtig ist, einen Überblick über unterschiedliche Auffassungen von transnationalen Literatur zu geben.

Das Ziel dieser Arbeit ist, den wissenschaftlichen Diskurs zur transnationalen Literatur in seinen wichtigsten Punkten wiederzugeben.

(C) Halytska O., 2020 